\title{
Conference report British Universities Siberian Studies Seminar: ninth conference report
}

\author{
Sergei S. Savoskul
}

The international, inter-disciplinary conference on 'Siberia, Land and Peoples: Destruction or Survival?' took place at the University of Leeds, UK, 6-8 September 2002. Its organiser was Dr David Collins, a specialist in the history of 18th- and 19th-century Siberia and head of the Department of Russian and Slavonic Studies at Leeds. This was the ninth conference of the British Universities Siberian Studies Seminar after an 11-year gap following the previous meeting, which took place in Kemerovo, September 1991, with the active participation of Russian scholars, particularly from the Siberian Branch of the Russian Academy of Sciences in Novosibirsk. ${ }^{1}$ The results of the previous conferences have appeared in three published books of articles written by the conference participants, ${ }^{2}$ and in earlier editions of Sibirica. Apart from the present conference's organiser, among those who have taken a leading role in previous gatherings have been Dr Alan Wood (Lancaster University, UK), historian of the pre-Revolutionary Siberian exile system; Professor Victor Mote (University of Houston, USA), an expert on the social and economic geography of Siberia; Dr Boris Chichlo (Institut d'études slaves, Paris, France, formerly of the Department of Ethnography, University of Leningrad); and Dr David Anderson (University of Aberdeen, UK), who specialises in the ethnography of northern Siberia. Among the Russian scholars who have taken an active role in the work of earlier conferences and in the publication of Sibirica was the renowned Siberian historian, the late Professor Leonid Goryushkin, formerly Director of the Institute of History,

Institute of Ethnology and Anthropology, Russian Academy of Sciences, Moscom (Translated by Alan Wood, Lancaster University, UK) 
Russian Academy of Sciences, Novosibirsk, and his successor, Professor Vladimir Shishkin. ${ }^{3}$

The interdisciplinary nature of the Leeds conference was manifested by the participation of representatives of a variety of academic specialists - historians, ethnographers (or, by western, Anglo-American tradition, social or cultural anthropologists), folklorists, linguisticians, and specialists in economic and social geography - all united in their common professional interest in Siberia. The conference also clearly demonstrated the growth of interest among western scholars in Russia's vast north-Asian territories, made particularly evident by the participation of a noticeably larger number of younger researchers, in comparison with previous meetings, as was noted by their 'veterans'. However, apart from the numbers, even more important, in my view, was the fact that the papers that were presented at the conference evinced an unquestionable development in the quality of Siberian studies in the west. In particular, this was quite obviously demonstrated by the researches of young western ethnologists, based on high quality fieldwork material gathered during long periods of living among the Siberian indigenous peoples they had investigated. Among these were the Telengit (Agnieszka Halemba, University of Cambridge, UK), the Khanty (Peter Jordan, University College, London, UK), the Yukagir (Rane Willerslev, University of Cambridge, UK), and the Chukchi (Patty Gray, Max Plank Institute for Social Anthropology, Halle, Germany). Moreover, all of these young scholars have a fluent command of Russian, and several of them also have a greater or lesser degree of competence in the languages of the ethnic groups which they are studying. All of this bears further witness to the high professional standard of a new generation of western scholars of Siberian ethnography.

The ethnographical theme was also pursued in two other interesting papers, one on 'Indigenous ethnonationalism in western Siberia, 1917-1919' which concentrated on the Turkic-speaking peoples of the Altai, and their efforts to establish an autonomous region during the post-revolutionary upheavals (Andrei Znamenski, Alabama State University, USA), and the other on the international ramifications of Soviet nationalities policy in the Far East in the 1920s and 1930s (Marina Fuchs, University of Konstanz, Germany). The seven conference participants from the Russian Federation also focussed on the ethnography and closely related topics in the study of Siberia. Their presentations evoked particular interests from the audience and demonstrated that Russian sibirevedenie, although not represented at this conference by internationally reputed and established doyens in the field, is nevertheless distinguished by the very high quality of their research. The Russian delegates at the conference included both younger and older scholar from Siberia itself, from the Urals, and from Moscow and St Petersburg. The topics of their papers were as follows: 'Ethno-political and social-cultural processes in the Altai, 1980s and 1990s' (Svetlana Tiukhteneva, Altai Institute, Gorno-Altaisk); 'Problems of language-learning and ethno-linguistic development among the Udegei' (Albina Girfanova, Institute of Linguistics, St Petersburg); 'Magic, shamanism 
and "participation"' (Nikolai Sukhachev, Institute of Linguistics, St Petersburg); 'Religious change among the Khanty: the historical perspective' (Elena Glavatskaia, University of the Urals, Iekaterinburg); 'The Orthodox Church and the religious situation in Siberia: tradition and modernity' (Sergei Filatov, Moscow State University); and 'Potanin's archive on the "world-map" of the Pribaikal peoples' (Elena Kovaliashkina, University of Tomsk).

Special attention was also given to the papers devoted to the scientific exploration and intellectual development of Siberia. They included those of Kristina Küntzel (Franckesche Stiftungen, Halle, Germany) on the RussoGerman project to publish the manuscripts of the leaders of the 'Second Kamchatka Expedition' (1733-1743), Georg Steller, Johann Fischer and Stepan Krasheninnikov, based on archive materials in St Petersburg and Halle, ${ }^{4}$ and Gudrun Bücher (Göttingen University, Germany) on 'Baron von Asch's papers and the Billings expedition, 1785-1792'. Further contributions on the scientific investigations of Siberia were contained in the papers by Elena Kovaliashkina mentioned above, and by the present author on the renowned ethnographer, B. O. Dolgikh and the Polar census of 1926-1927.

Among the historians, the conference organiser, David Collins (University of Leeds, UK), presented a paper on Russia's occupation of the Altai as a 'fortified resource frontier' (1747-1850), and Christopher Witzenrath (King's College, London) offered an entertaining account of the role of cossak bands in the commercial, administrative and political life if Siberia in the 17th and 18th centuries.

Geographers, too, made significant contributions, for example: Professor Michael Bradshaw (University of Leicester, UK) gave an illustrated presentation on 'Globalisation and regional change in the Russian Far East: the case of Sakhalin', and Professor Victor Mote (University of Houston, Texas) provided a descriptive analysis of Stalin's 'Road of Death', the disastrous attempt to build an Arctic railroad from the northern Urals to the Chukchi peninsula in the late 1940s. Thousands perished in the doomed enterprise, which was abandoned immediately after Stalin's death in 1953.

Unfortunately, the first issue of the new Sibirica had not appeared in time for the conference, but Alan Wood, founder and current co-editor of the journal, gave a brief account of its origins and recent history, and provided page-proofs of the new publication, kindly supplied by the publishers for advance inspection by conference participants.

At the closing session, Professor Mote proposed the University of Houston, Texas, as the venue for the next Siberian Studies conference. Arrangements are currently under way, and the meeting is scheduled for April 2004.

\section{Notes}

1 For more details, see Sibirica 2, no. 1 (2002): p. 3.

2 See A. Wood, ed., Siberia: Problems and Prospects for Regional Development (London, 
New York, Sydney, 1987); A. Wood and R. A. French, eds, The Development of Siberia: People and Resources (London, 1989); A. Wood, ed., The History of Siberia: From Russian Conquest to Revolution (London and New York, 1991).

3 For Goryushkin's obituary, see Sibirica 2, no. 1 (2002): pp. 8-11.

4 Volumes 1 and 2 of the published materials are reviewed in Sibirica 2, no. 1 (2001, 2002): pp. 118-9. 